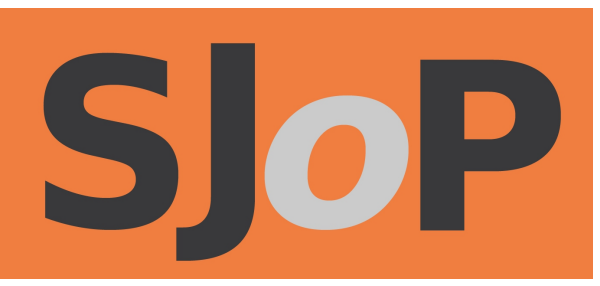

Book review: The reflexive teaching artist: collected wisdom from the drama/theatre field, by Kathryn Dawson and Daniel A. Kelin

\title{
LAURA BISSELL
}

The Scottish Journal of Performance

Volume 2, Issue 1; December 2014

ISSN: 2054-1953 (Print) / ISSN: 2054-1961 (Online)

Publication details: http://www.scottishjournalofperformance.org

To cite this article: Bissell, L., 2014. Book review: The reflexive teaching artist: collected wisdom from the drama/theatre field, by Kathryn Dawson and Daniel A. Kelin. Scottish Journal of Performance, 2(1): pp.139-142.

To link to this article: http://dx.doi.org/10.14439/sjop.2014.0201.13

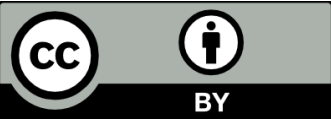




\title{
Book Review: The reflexive teaching artist: collected wisdom from the drama/theatre field, by Kathryn Dawson and Daniel A. Kelin
}

\author{
LAURA BISSELL
}

DOI: 10.14439/sjop.2014.0201.13

Publication date: 15 December 2014

The reflexive teaching artist: collected wisdom from the drama/theatre field, by Kathryn Dawson and Daniel A. Kelin, II. Bristol: Intellect, 2014; ISBN 9781783202218 (£28.00)

The Reflexive Teaching Artist: Collected Wisdom from the Drama/Theatre Field by Kathryn Dawson and Daniel A. Kelin, II develops ideas of the role of the teaching artist explored previously by Eric Booth (who provides the foreword) in The Music Teaching Artist's Bible (2009) and also aims to further explicate the role of reflective practice for those working in the drama/theatre field. Referencing key theorists in the field of educational theory such as Phil Race (author of The Lecturer's Toolkit) and others, Dawson and Kelin offer an 'interactive text' with exercises and reflective tasks for the reader to apply to their own practice. In my role as Lecturer in Contemporary Performance Practice at the Royal Conservatoire of Scotland, I consider ideas around reflective practice/praxis and the development and design of assessment and so this text was highly relevant to my own teaching practice.

This study is building on previous models of reflective practice for artists working in the drama/theatre sector and provides an overview of many key ideas in this area such as: 'Reflection', ‘Collected Wisdom', ‘Quality', 'Artistic 
Perspective', 'Assessment', and 'Praxis'. Within each of the sections there is a diverse and vibrant range of examples of practice from school, community, and professional theatre settings. Written in the first person or in the form of an interview, these case studies of reflexive practice offer refreshingly honest and varied examples of approaches from a diverse range of geographical and cultural positions. Amanda Hashagen offers reflections on devised performance in a gender-specific juvenile probation program in the early 'Collected Wisdom' section, while in 'Assessment' Ryan Conarro reflects on his experiences of creating a community documentary project in rural Alaska. Christina Marin shares her thoughts on how drama praxis and Latino leadership intersect in the final 'Praxis' section, which also offers a critique of current perceptions of what the term 'praxis' encompasses. The inclusion of multiple, concise reflections in each section allow for a multivocality of voices, while each sharing of experience or 'wisdom' emphasises the importance of reflective practice in accordance with the overall theme of the book.

One of the contributors, Roxanne Schroeder-Arce, identifies her practice as 'culturally responsive teaching' (p.60), and many of the artists and educators who share their practice reflect on their previous attempts to enforce their own ideologies and methodologies on to a group of students without understanding the context or the needs of the group. Several of these reflections stress the importance of listening to and responding to the specific group, and suggest that flexibility and a willingness to show vulnerability as a facilitator is vital in educational contexts. Many reflexive practitioners cited highlight their own learning and development throughout their teaching experiences. The role of reflective practice as a tool for developing and improving your artistic and educational practice is a key tenet of this study. 
The authors write from the perspective of teaching artists themselves and the dual authorship allows for Dawson and Kelin's personal accounts and motivations to frame the book before opening the conversation to a wide range of perspectives. This co-authored introduction is in keeping with the study as a whole which collates numerous voices in the field. An action-research model is introduced at the outset of the text, then the idea of 'Collected Wisdom' of the title is realised through the varied contributions. The authors include guided reflective activities for the reader to carry out to relate their own practice to the ideas explored, although these appear most frequently at the beginning and end of the book as these sections focus mainly on the sharing of reflexive/reflective practice from artists and educators. The tasks are useful in attempting to demonstrate the 'praxis' that the authors are keen to fully explore, but these could have been interspersed throughout the volume more consistently in order for them to feel embedded within the text and for it to feel more 'interactive'.

I would highly recommend this text to teaching artists working in the drama/theatre field. The authors acknowledge their use of both 'drama' and 'theatre' in their title and justify their inclusion of both terms. While the definitions they provide for these concepts are quite specific, the examples of practice open up these terms to illustrate the commonalities in experiences of teaching in an artistic/educational context without making generalisations. The case studies are all recent and relevant, honest in tone, and genuinely reflexive, providing a refreshing perspective on the role of the contemporary artist/educator. The authors advocate Booth's philosophy behind the concept of the 'teaching artist': that the individual who creates the learning environment is important. The collated voices and experiences throughout The Reflexive Teaching Artist testify to the practitioners' own learning experiences encountered as educators and artists in the field. This study includes high-quality 
reflection on the issues surrounding the role of the teaching artist in the drama/theatre sector, while reflective exercises offer practical ways to embed these ideas and concepts into an existing teaching practice.

\section{References}

Booth, E., 2009.The music teaching artist's bible. Oxford: Oxford University Press.

Race, P., 2006. The lecturer's toolkit: a practical guide to learning, teaching and assessment. London: Routledge.

\section{About the review author}

DR LAURA BISSELL is a Lecturer in Contemporary Performance Practice within the School of Drama at the Royal Conservatoire of Scotland. Laura is a visiting lecturer on the MRes in Creative Practices programme at the Glasgow School of Art and has presented her research on contemporary practices at conferences nationally and internationally. 